Board of Governors of the Federal Reserve System

\author{
International Finance Discussion Papers
}

Number 1014

February 2011

International Capital Flows and the Returns to Safe Assets in the United States, 2003-2007

Ben S. Bernanke, Carol Bertaut, Laurie Pounder DeMarco, and Steven Kamin

NOTE: International Finance Discussion Papers are preliminary materials circulated to stimulate discussion and critical comment. References to International Finance Discussion Papers (other than an acknowledgment that the writer has had access to unpublished material) should be cleared with the author or authors. Recent IFDPs are available on the Web at www.federalreserve.gov/pubs/ifdp/. This paper can be downloaded without charge from Social Science Research Network electronic library at www.ssrn.com. 


\title{
International Capital Flows and the Returns to Safe Assets in the United States, 2003-2007
}

\author{
Ben S. Bernanke, Carol Bertaut, Laurie Pounder DeMarco, and Steven Kamin*
}

\begin{abstract}
A broad array of domestic institutional factors - including problems with the originate-todistribute model for mortgage loans, deteriorating lending standards, deficiencies in risk management, conflicting incentives for the GSEs, and shortcomings of supervision and regulation-were the primary sources of the U.S. housing boom and bust and the associated financial crisis. In addition, the extended rise in U.S. house prices was likely also supported by long-term interest rates (including mortgage rates) that were surprisingly low, given the level of short-term rates and other macro fundamentals - a development that Greenspan (2005) dubbed a “conundrum.” The "global saving glut” (GSG) hypothesis (Bernanke, 2005 and 2007) argues that increased capital inflows to the United States from countries in which desired saving greatly exceeded desired investment—including Asian emerging markets and commodity exporters_were an important reason that U.S. longer-term interest rates during this period were lower than expected.
\end{abstract}

This essay investigates further the effects of capital inflows to the United States on U.S. longer-term interest rates; however, we look beyond the overall size of the inflows emphasized by the GSG hypothesis to examine the implications for U.S. yields of the portfolio preferences of foreign creditors. We present evidence that, in the spirit of Caballero and Krishnamurthy (2009), foreign investors during this period tended to prefer U.S. assets perceived to be safe. In particular, foreign investors-especially the GSG countries - acquired a substantial share of the new issues of U.S. Treasuries, Agency debt, and Agency-sponsored mortgage-backed securities. The downward pressure on yields exerted by inflows from the GSG countries was reinforced by the portfolio preferences of other foreign investors. We focus particularly on the case of Europe: Although Europe did not run a large current account surplus as did the GSG countries, we show that it leveraged up its international balance sheet, issuing external liabilities to finance 
substantial purchases of apparently safe U.S. "private-label” mortgage-backed securities and other fixed-income products. The strong demand for apparently safe assets by both domestic and foreign investors not only served to reduce yields on these assets but also provided additional incentives for the U.S. financial services industry to develop structured investment products that "transformed" risky loans into highly-rated securities.

Our findings do not challenge the view that domestic factors, including those listed above, were the primary sources of the housing boom and bust in the United States. However, examining how changes in the pattern of international capital flows affected yields on U.S. assets helps provide a deeper understanding of the origins and dynamics of the crisis.

Keywords: Global saving glut, interest rates, capital inflows, mortgage-backed securities JEL Classifications: F3, G1

*The authors are, respectively, Chairman of the Board of Governors of the Federal Reserve System, and staff economists in the Division of International Finance, Board of Governors of the Federal Reserve System, Washington, D.C. 20551 U.S.A. This paper was prepared for the Banque de France Financial Stability Review (No. 15, February 2011). The views in this paper are solely the responsibility of the author(s) and should not be interpreted as reflecting the views of the Board of Governors of the Federal Reserve System or of any other person associated with the Federal Reserve System. We would like to thank Andreas Lehnert, Geng Li, Karen Pence, and Shane Sherlund for their help putting together the data for this project, as well as many colleagues at the Board for helpful comments. James Coonan provided superb research assistance. 


\section{Introduction}

The U.S. housing boom and the bust that followed resulted from the interaction of a wide range of factors, including problems with the originate-to-distribute model for mortgage loans, a deterioration in loan underwriting standards, deficiencies of risk management among financial institutions, contradictions in the incentive structures of the government-sponsored enterprises (GSEs), and problems in the scope and implementation of financial supervision and regulation (Dokko et. al. 2009; Bernanke, 2010). In addition to these domestic institutional factors, international capital flows likely played a significant role in helping to finance the housing bubble and thus set the stage for its subsequent bust. Bernanke $(2005,2007)$ argued that an increase in notional saving relative to investment in many emerging market countries had given rise to a "global saving glut" (GSG), with capital flows to the United States helping hold down U.S. longer-term interest rates earlier in the decade. Lower long-term interest rates, including mortgage rates, in turn contributed to the extended rise in house prices.

In this essay, we build on the GSG hypothesis to flesh out a more complete story of how international capital flows affected the pattern of longer-term yields in the United States. First, whereas the GSG hypothesis is based on a simple framework in which global saving and investment decisions determined the return on a single asset, we now consider how demands for a range of assets interacted with supplies of those assets to help produce declines in certain key interest rates. More specifically, in the spirit of Caballero and Krishnamurthy (2009), we analyze the channels through which the demand for apparently safe assets by foreigners contributed to their substantial acquisitions not only of U.S. Treasury securities (Treasuries) and Agency debt (Agencies), but also of highly rated, privately issued mortgage-backed securities 
(MBS) and other structured investment products backed by U.S. residential mortgages. ${ }^{1}$ Second, whereas the GSG hypothesis focused mainly on capital flows into the United States from emerging market economies running current account surpluses_primarily developing Asian economies and oil exporters - this essay shows how capital inflows from other advanced economies also helped to suppress yields on apparently safe assets, including mortgages.

Finally, we discuss how the demand for apparently safe assets influenced their supply, as the U.S. financial services industry developed a multitude of structured investment products that transformed risky loans into highly rated securities.

All told, our framework expands the simple GSG hypothesis to better explain the role international capital flows played in reducing yields on mortgages and other apparently safe assets. The analysis focuses on the period from 2003 to 2007, which encompasses the years when capital inflows into the United States were strongest, Treasury yields were most depressed, and the U.S. housing boom was at its peak. First, we verify that the "GSG countries"-that is, emerging Asia and Middle Eastern exporters—did indeed evince a strong preference for the safest U.S. assets. ${ }^{2}$ On the margin, this preference most likely helped push down yields on MBS relative to other assets, as most MBS were either guaranteed by the Agencies or sold as tranches carrying AAA credit ratings.

Second, the downward pressure on yields exerted by inflows from the GSG countries was reinforced by the portfolio preferences of other foreign investors. We focus particularly on the case of Europe. Europe did not run a current account surplus as did the GSG countries, and thus

\footnotetext{
1 “Agency” refers to the GSEs, most notably Fannie Mae and Freddie Mac, designed to promote homeownership by supporting the secondary market for residential mortgages. These enterprises both guaranteed MBS and purchased them for their own portfolios. Here and throughout this paper, Agency debt refers to both unsecured debt and Agency-guaranteed MBS.

${ }^{2}$ In the calculations described later, the GSG countries are taken to include all countries of Asia and the Middle East excluding Japan. This group, although not exhaustive, accounts for the lion's share of investment in the United States by emerging market economies.
} 
was not a net exporter of saving to the rest of the world. But Europe leveraged up its international balance sheet significantly, issuing, among other instruments, considerable sovereign debt and bank debt, and using the proceeds to buy substantial amounts of highly rated U.S. MBS and other fixed-income products. In fact, the strong preference of the GSG countries for Treasuries and Agencies appears to have pushed Europeans and other advanced-economy investors, including U.S. investors, into apparently safe “private-label” MBS.

Finally, the demand for safe assets by investors, both domestic and foreign, appears to have engendered a strong supply response from U.S. financial firms. In particular, even though a large share of new U.S. mortgages during this period were of lower credit quality, such as subprime loans, Agency guarantees and financial engineering in the private financial services industry resulted in the overwhelming share of mortgage-related securities being rated AAA. Of course, following the onset of the housing bust and financial crisis, the underlying weakness of these securities became evident.

To be clear, in no way do our findings assign the ultimate causality for the housing boom and bust to factors outside the United States. Domestic factors, including those listed in the first paragraph of this paper, were the primary sources of the boom and bust and the associated financial crisis. However, an examination of how changes in the pattern of international capital flows affected yields on U.S. assets is important for understanding the origins and dynamics of the crisis.

\section{The Global Saving Glut and Returns to Treasury and Agency Securities, 2003- 2007}

Our research is motivated by two puzzles in the evolution of interest rates during the period leading up to the financial crisis. The first of these puzzles is the very low level of longterm Treasury security yields, which remained relatively contained even as the federal funds rate 
was raised from 1 percent to an eventual level of 51/4 percent (Figure 1). Greenspan (2005) famously referred to this development as a “conundrum,” and various studies showed that bond yields, both in the United States and abroad, fell below levels that were consistent with standard macro fundamentals such as inflation, growth in gross domestic product, and fiscal balances (Rudebusch, Swanson, and Wu, 2006; Gruber and Kamin, 2009). The second, related puzzle is the sustained low level of mortgage interest rates, also shown in Figure 1. While part of the weakness in these rates obviously is due to the low Treasury yields, the spread of mortgage rates over Treasury yields also edged down over the period, notwithstanding a sharp step-up in the pace of mortgage issuance; the outstanding stock of MBS and unsecuritized mortgages rose from \$6.4 trillion at the end of 2002 to \$11.1 trillion in 2007.

Of these two puzzles, the first has probably received the most attention. There are a number of explanations for the weakness in Treasury yields during this period, including declines in risk premiums (perhaps, at least initially, associated with the "great moderation”) and enhanced demands for long-term assets by pension funds and other institutional investors. In addition, observers have come to attribute at least part of the weakness of long-term bond yields to heavy purchases of securities by emerging market economies running current account surpluses, particularly emerging Asia and the oil exporters. Bernanke (2005, 2007) argued that in these countries, investment rates had fallen short of desired saving, creating a global saving glut that resulted in net capital outflows to the rest of the world and, as a consequence, declines in long-term interest rates. In fact, empirical research for the most part confirms that such acquisitions had a statistically significant downward effect on bond yields. ${ }^{3}$

\footnotetext{
${ }^{3}$ Bernanke, Reinhart, and Sack (2004) find that Treasury yields declined significantly during intervals around Japanese interventions to purchase dollars in the 2000-04 period. Warnock and Warnock (2009) estimate regressions of U.S. 10-year bond yields on standard macroeconomic variables as well as foreign official purchases
} 
What factors led to the excess saving (or dearth of investment) and the resulting current account surpluses of the GSG countries? Certainly, some of these surpluses were due to the 1997-98 Asian financial crisis, which substantially reduced investment in emerging Asia, as well as to the run-up in oil and commodity prices in the following decade, which provided commodity exporters with more revenues than they could spend productively at home in the near term. High saving rates in rapidly growing emerging-market economies also contributed to the surpluses. Although this analysis helps explain the sources of the GSG, it has the shortcoming of treating all forms of saving and the resulting capital flows as homogeneous. By contrast, an interesting recent body of literature has focused on the portfolio preferences embodied in capital flows to advanced economies. Specifically, it proposes that these emerging market economies sought safe, high-quality financial assets that their own governments and financial systems could not provide but were being produced in the advanced economies. ${ }^{4}$ Accordingly, the emerging market economies were willing to run current account surpluses in order to finance the acquisition of these safe assets (Caballero, Farhi, and Gourinchas, 2008; Mendoza, Quadrini, and Rios-Rull, 2007). Moreover, the notable depth, breadth, and apparent safety of U.S. financial markets led the emerging market economies to direct most of their capital outflows to the United States (Blanchard, Giavazzi, and Sa, 2005; Clarida, 2005; Cooper, 2005; Hubbard, 2005). If confirmed, this hypothesis about the foreign demand for safe assets could explain the strength of the capital flows from emerging market economies to advanced economies with deep capital

of U.S. Treasury and Agency bonds; they find that foreign purchases significantly lowered U.S. Treasury yields, including by some 90 basis points in 2005. Conversely, Rudebusch, Swanson, and Wu (2006) estimate term structure models of Treasury yields and find that foreign official holdings have no explanatory power. Beltran, Kretchmer, Marquez, and Thomas (2010) find that these models are sensitive to changes in variable definitions and econometric specification, but conclude that, overall, foreign official inflows likely pushed down Treasury yields.

${ }^{4}$ The demand for these safe assets may have included the demand for international reserves by emerging market economy governments. Most of the acquisitions of U.S. assets by GSG countries were in the form of official inflows. 
markets, such as the United States. It could also explain why yields on the safest U.S. assets, Treasuries and Agencies, were so low.

So, did the emerging market economies running current account surpluses generally acquire safe, liquid assets, primarily in the United States? The answer appears to be yes. ${ }^{5}$ Figure 2 compares the current account balances of three major categories of GSG economies-China, other emerging Asian economies, and the Organization of the Petroleum Exporting Countries (OPEC) — with such measures as are available of their overseas asset purchases. ${ }^{6}$ On net, China's current account surpluses were used almost wholly to acquire assets in the United States, more than 80 percent of which consisted of very safe Treasuries and Agencies. The other emerging Asian economies used their current account surpluses to purchase roughly equal amounts of safe U.S. assets and European bank deposits. Data on the allocation of OPEC assets, unfortunately, is incomplete, but it is likely that a good portion of their investments abroad went into purchases of U.S. and European assets that are held by third-party custodians.

Figure 3 examines the portfolio preferences of the GSG countries from a different angle, comparing the mix of these countries' holdings of U.S. securities in 2007 to the mix of U.S. securities outstanding at that time, and produces a reinforcing result. More than three-fourths of the GSG countries’ U.S. security holdings consisted of AAA-rated debt, mainly Treasuries and Agencies, whereas these categories account for only 36 percent of total U.S. securities outstanding.

\footnotetext{
${ }^{5}$ See also Brender and Pisani (2010).

${ }^{6}$ Comprehensive data on overseas asset purchases by these countries not available. Therefore, we have attempted to capture these purchases by combining data on GSG-country acquisitions of U.S. assets, based on U.S. balance-ofpayments, Treasury International Capital (TIC), and Bank for International Settlements (BIS) banking data, with GSG net bank flows to Europe, based on BIS banking data. Unfortunately, data on foreign purchases of non-U.S. securities, which likely represent the largest gap in our coverage, are not available for most GSG countries.
} 
Moving from the one-asset framework underlying the original GSG hypothesis to a multi-asset framework that allows for assets of different degrees of riskiness, the story of how capital inflows from the GSG countries ultimately helped to depress interest rates on U.S. assets perceived to be safe, including mortgages, becomes only a bit more complicated. GSG acquisitions of U.S. Treasuries and Agencies took these assets off the market, creating a notional scarcity that boosted their price and reduced their yield. Because GSG investments were for purposes of reserve accumulation and guided by considerations of safety and liquidity, those countries continued to concentrate their holdings in Treasuries and Agencies even as the yields on those securities declined. However, other investors were now induced to demand more of assets considered substitutable with Treasuries and Agencies, putting downward pressure on interest rates on these private assets as well. Thus, the interest rates on conforming mortgages shown in Figure 1 declined from their levels at the start of the decade. ${ }^{7}$

For capital inflows from the GSG countries to have put downward pressure not only on Treasury and Agency yields, but also on returns on other safe assets such as highly rated privatelabel MBS, several conditions would have had to be met. First, GSG inflows would have needed to be focused on the safest U.S. assets. Second, these inflows would have had to have been sizable relative to the total net issuance of apparently safe assets in the United States. Figure 4 presents mixed evidence on this point. It compares gross capital inflows into apparently "safe" U.S. securities—Treasuries, Agencies, and AAA-rated private debt— from a number of regions with the increase in the total outstanding stock of safe U.S. securities. On the one hand, acquisitions of safe assets by the GSG countries stepped up sharply from the 1998-2002 period to the 2003-2007 period, both in dollar terms and as a fraction of total net issuance. On the other

\footnotetext{
${ }^{7}$ See also the discussions of the effects of capital inflows, especially from the GSG countries, on the U.S. financial market in Caballero and Krishnamurthy (2009); Jagannathan, Kapoor, and Schamnurg (2009); Brender and Pisani (2010); Bertaut, DeMarco, Kamin, and Tryon (2010); and Linde, Martin and Vigfusson (2010).
} 
hand, during the later period, inflows from the GSG countries alone accounted for less than onefourth of the total increase in the stock of safe U.S. securities. Therefore, one may question whether the effect of GSG inflows on the yields of safe U.S. assets outside the circle of Treasuries and Agencies, such as private-label MBS, was all that sizable.

Whereas GSG inflows may not have risen sufficiently to exert a strong downward effect on safe asset yields in the private sector, inflows from all foreign sources may have been large enough to play this role. Figure 4 shows that such inflows rose sharply in the 2003-07 period, accounting for more than one-half of the net issuance of highly rated U.S. assets. To explain the behavior of safe asset yields in this period, it may therefore be useful to expand the analysis to include investments by other foreigners besides the GSG countries, which we will do in the next section.

\section{The Demand for Safe U.S. Assets by the Advanced Foreign Economies}

As indicated above, a large share of the highly rated securities issued by U.S. residents from 2003 to 2007 was sold to foreigners — 55 percent. This share was even higher than in the 1998-2002 period—22 percent—even though total net issuance of apparently safe assets rose from $\$ 3.1$ trillion in the first period to $\$ 4.5$ trillion in the second. (The net issuance of privatelabel AAA-rated asset-backed securities outstanding, including MBS, rose from \$0.7 trillion in the first period to $\$ 2$ trillion in the second.) That both the level of mortgage interest rates and their spread over Treasury yields could decline during the recent decade, notwithstanding substantial issuance of mortgages, would seem attributable, in part, to the strong demand for safe assets by foreigners. 
Among the advanced economies, the most prominent source of gross capital flows into AAA-rated U.S. securities from 2003 to 2007 was Europe. ${ }^{8}$ As indicated in Figure 4, these acquisitions stepped up markedly from the 1998-2002 period and were nearly as large as those of the GSG countries. Moreover, Figure 4 likely understates Europe’s purchases of apparently safe U.S. assets, because it depicts purchases of only the safest (AAA-rated) assets. Unlike the GSG countries, whose net purchases of U.S. assets during the period consisted almost exclusively of Treasuries and Agencies, Europeans bought a much wider range of assets, shown in Figure 5. In addition to AAA-rated securities, Europeans purchased substantial amounts of non-AAA-rated securities, particularly corporate bonds_-many of these, while not receiving the highest rating, were nonetheless investment grade. Accordingly, taking into account both European purchases of AAA-rated securities and those that were just a little less highly rated, net European acquisitions of apparently safe U.S. assets (more broadly construed) almost certainly exceeded those of the GSG countries.

Although Europe’s demands for apparently safe U.S. assets thus substantially reinforced those of the GSG countries, there were some important differences between these two groups of investors. First, as noted earlier, European asset preferences were considerably broader than those of the GSG countries. Returning to Figure 3, it is clear that European investors held a much smaller share of their portfolio of U.S. assets in Treasuries and Agencies than did the GSG countries, while holding a much larger share in AAA-rated asset-backed securities (including private-label MBS), as noted previously, as well as in equities and lower-rated debt. In fact, by our estimates, the share of the most highly rated securities in Europeans' U.S. portfolios was

\footnotetext{
${ }^{8}$ In the statistics presented in this paper, Europe is represented as the euro area plus the United Kingdom, with financial claims between them netted out.
} 
about the same as in the total amount of U.S. securities outstanding. ${ }^{9}$ As regards the riskier assets, Europeans held a smaller share of equities, but appear to have held a somewhat larger share of lower-rated instruments, including both corporate debt and asset-backed securities, than the market capitalization benchmarks.

Accordingly, European investments in the United States seem unlikely to have been motivated exclusively by the same objective—-the acquisition of very safe, liquid financial assets - as the investments of the GSG countries. Rather, European investors appear to have targeted a portfolio that was riskier than that held by the GSG countries and, indeed, broadly similar to the mix of U.S. securities outstanding. As to what accounted for the substantial increase in European holdings of U.S. assets—including MBS—during the 2003-07 period, a number of explanations seem plausible. First, as in the United States, reductions in longer-term interest rates in Europe undoubtedly generated interest in assets such as U.S. MBS that offered slightly higher returns while still being highly rated. Second, Europe started this period with a relatively pronounced degree of "home bias" in its investments, and generalized declines in home bias around the world as financial globalization progressed likely also motivated acquisitions of U.S. assets (Bertaut, 2008). Third, much of the investment in U.S. MBS around the world came from the expanding off-balance-sheet vehicles of large global banks, and many of those banks were located in Europe (Arteta, Carey, Correa, and Kotter, 2009). A final possibility, advanced by Acharya and Schnabl (2010) among others, is that the regulatory capital

\footnotetext{
${ }^{9}$ The composition of foreigners' holdings of U.S. assets shown in Figure 3 is based on the TIC data. These data specify the types of instruments held-e.g., Treasuries, Agencies, corporate debt, MBS and other asset-backed securities, equities - but not their credit ratings. The breakdown of corporate debt and MBS into AAA and nonAAA shares is based on the rating shares for the total amounts outstanding of these securities. Because nearly all U.S. MBS was rated AAA (see Section IV below), our estimate of the AAA share of European-held MBS is likely to be approximately correct. For European holdings of corporate debt, the breakdown by credit rating is more uncertain.
} 
charges levied on banks that set up off-balance-sheet conduits to invest in U.S. MBS were inadequate, which also served to encourage investments in these assets.

A second difference between the GSG and European investors is that, whereas the GSG countries were running current account surpluses and investing their accumulated wealth in U.S. securities, Europe was running roughly balanced current accounts and was financing its acquisition of U.S. securities through external borrowing. Figure 6 shows the growth in Europe's gross international claims and liabilities over the period 2003-07. The fact that Europe was issuing external liabilities and acquiring external assets in roughly equal quantities does not mean, however, that the net effect of these transactions on global financial markets was a “wash.” Figure 7 depicts the evolution of Europe’s international balance sheet from 2003 to 2007, showing how its acquisition of external claims was financed by issuance of external liabilities. The composition of these flows of claims and liabilities was broadly similar, but the rise in claims included significant amounts of asset-backed securities and other complex financial instruments, whereas the rise in liabilities was tilted toward traditional securities and bank deposits.

Specifically, and focusing first on securities, Figure 7 shows that much of Europe’s issuance of externally held securities was in the form of equity and sovereign debt, whereas much of its acquisition of external securities was in the form of asset-backed securities and other debt securities issued by foreign financial corporations, most of which ultimately were issued in the United States. ${ }^{10}$ Turning to transactions among banks and other primarily financial

\footnotetext{
${ }^{10}$ Sovereign debt refers to debt issued by governments. While capital inflows to purchase European sovereign debt helped finance the acquisition of external assets by Europe as a whole, there is no presumption that these inflows financed external asset accumulation by European governments themselves. No sovereign debt appears on the asset side of the balance sheet shown in Figure 7 because the change in Europe's holdings of foreign sovereign debt over the period was negligible.
} 
institutions, Europe was a net lender abroad to nonbank corporations ("net loans to nonbanks and other”), but was a net recipient of international interbank flows and other deposits from abroad (“net interbank and deposits”) during this period. ${ }^{11}$ As became apparent after the financial crisis broke, many European financial institutions were funding their purchases of U.S. assets with short-term dollar-denominated liabilities like commercial paper or bank deposits, much of which attracted U.S. investors (McGuire and von Peter, 2009, Acharya and Schnabl, 2010). ${ }^{12}$

Thus, even though Europe was not running current account surpluses, its financial firms and investors engaged in a process of intermediation which augmented the supply of financing for MBS and related instruments, especially in the United States. As Acharya and Schnabl (2010) point out, investment inflows from current account deficit countries as well as surplus countries were both quite significant for U.S. financial markets.

Table 1 fleshes out the interplay between changes in the supply and demand for various U.S. securities during the period of the housing boom. Between year-end 2003 and year-end 2007, the value of total U.S. securities outstanding rose about $\$ 10$ trillion, of which roughly $\$ 4 \frac{1}{2}$ trillion was absorbed by foreign investors. ${ }^{13}$ The supply of Treasuries and Agencies outstanding rose $\$ 1.6$ trillion, and this was fully taken up by foreigners (on net), of which $\$ 0.9$ trillion was

\footnotetext{
${ }^{11}$ Because the gross two-way flows between Europe and the rest of the world are so large for the "Net loans to nonbanks and other" and "Net interbank and deposits" categories, we show only their net flows in Figure 7. "Net loans to nonbanks and other" primarily contains long-term bank loans to nonbank corporations, intercompany loans between nonbank corporations, and certain transactions by brokers. "Net interbank and deposits," in addition to interbank flows and deposits from nonbank residents abroad, also includes estimates of net repurchase agreements transacted by nonbank corporations, such as brokers. These two categories are derived from and completely cover the "Other Investment" category of the Financial Accounts of the balance of payments of the euro area and the United Kingdom. But in order to present these categories on the basis shown in Figure 7, we also used data from the BIS, individual European countries' Financial Accounts, and the U.S. Financial Account.

${ }^{12}$ It should be noted that not all of the dollar funding of U.S. asset-backed securities by Europeans is captured by these data. In many cases, U.S. subsidiaries of European institutions, including their off-balance-sheet vehicles, both received dollar-funding and purchased asset-backed securities in the United States or the Caribbean; accordingly, these transactions did not give rise to the cross-border financial flows with Europe shown in Figure 7. This is particularly true of dollar funding through commercial paper vehicles.

${ }^{13}$ Part of the increase in the value of these securities is due to valuation changes for equities; valuation changes for the debt securities were likely fairly small.
} 
purchased by the GSG countries and less than $\$ 0.2$ trillion by Europeans. The amount outstanding of AAA-rated asset-backed securities rose \$1.7 trillion, of which U.S. residents took $\$ 1.1$ trillion and Europeans $\$ 0.4$ trillion. ${ }^{14}$ All told, as indicated by line 11 , the share of the increase in the value outstanding of U.S. securities absorbed by foreigners ranged from 182 percent for AAA-rated corporate securities—-that is, foreigners ultimately absorbed all of the new issuance of these securities and bought some from U.S. residents, too- to only 25 percent for equities.

Overall, the substantial net capital inflows financed by the current account surpluses of the GSG countries, coupled with the substantial gross capital inflows from Europe—as they issued sovereign debt and bank deposits, among other liabilities, to acquire U.S. structured instruments—-probably raised net demands for apparently safe U.S. assets. Together with the original GSG hypothesis, this likely helps to explain why U.S. assets perceived to be safe, including MBS, saw little change in yields despite tightening monetary policy and heavy issuance of mortgages.

\section{Changes in the Supply of Apparently Safe U.S. Assets}

Given the strength of demand for safe U.S. assets, it would have been surprising had there not been a corresponding increase in their supply. Caballero and Krishnamurthy (2009) argue that the desire to accommodate the demand for safe assets by global investors was a prominent factor in a process that transformed risky loans into highly rated securities. As shown in the top panel of Figure 8, during the U.S. housing boom, not only was there a surge in origination of

\footnotetext{
${ }^{14}$ These figures may understate somewhat the amount of U.S. asset-backed securities that were ultimately owned by Europeans. Many off-balance-sheet vehicles of European banks were located in the United States, and purchases of asset-backed securities by these vehicles would be recorded as purchases by "U.S. residents." In addition, many vehicles of European and U.S. global banks were located in offshore financial centers, where much of the remaining $\$ 0.3$ trillion in U.S. asset-backed securities were held.
} 
new mortgage loans, but the share of these loans that were considered riskier-subprime and variable-rate prime including alt A—rose substantially as well. And yet, remarkably, as depicted in the bottom panel, nearly all the surge in asset-backed securities outstanding is estimated to have been rated AAA.

Figure 9 examines the AAA-rated shares of different categories of private securities. ${ }^{15}$ The share of private-label asset-backed securities that was rated AAA during the housing boom, at about 85 percent, dramatically exceeded the AAA-rated share of financial corporate bonds (15 percent) and nonfinancial corporate bonds (3 percent). Moreover, whereas the AAA-rated share of corporate bonds was flat or declining during the height of the housing boom, the AAA-rated share of private-label MBS rose slightly.

The process by which collections of loans, many of dubious quality, were transformed into highly rated structured investment products has been well covered by Gorton (2008, 2009) and Coval, Jurek, and Stafford (2008), among others. In brief, pooling loans and establishing tranches with a pre-established priority ordering for payments allowed many securities to be deemed much safer than the average loan in the underlying pool. The motivation for this financial engineering was clear: There were profits to be made by selling securities at a price that ultimately proved much higher than the value of the underlying collateral. But, equally important, it was recognized that the willingness of investors to deliberately take on additional risk was limited. Investors were willing to reach for some additional yield by purchasing AAArated MBS rather than Agency debt (or sovereign bonds at home), but they likely would not have absorbed BBB-rated MBS in significant quantities. Accordingly, the surge in financial engineering to tranche the payouts from mortgages so as to create highly rated debt securities

\footnotetext{
${ }^{15}$ Data on credit ratings for corporate bonds were obtained from Moody’s DRS data. Data on credit ratings for outstanding MBS were estimated based on new-issue ratings in Dealogic data.
} 
was, at least in part, an endogenous response to the risk preferences of domestic and foreign investors. (See Nadauld and Sherlund, 2009; Gerardi, Lehnert, Sherlund, and Willen, 2008; and Mayer, Pence, and Sherlund, 2009.)

The combination of heavy demand for highly rated MBS, along with the transformation of risky mortgages into highly rated MBS by the financial services industry, increased the effective demand for "raw materials" - that is, new mortgage originations. As indicated in Figure 10, issuance of subprime adjustable-rate mortgages (ARMs) soared during this period, but spreads of the interest rates on these mortgages relative to those on conforming ARMs (which were guaranteed by the GSEs) continued to decline. The growing demand for securities backed by these loans on the part of investors, both foreign and domestic, helped keep these spreads low.

\section{Conclusion}

In this paper, we have argued that international capital inflows likely played an important role in lowering Treasury yields and returns on other apparently safe U.S. assets, especially mortgages, in the years leading up to the financial crisis. As highlighted by both the GSG hypothesis and the more recent literature focusing on the international pattern of asset supplies and preferences, these capital inflows included purchases of Treasuries and Agencies by emerging market economies seeking safe assets in which to invest their current account surpluses. However, these capital inflows also included purchases of highly rated private-label MBS by investors in other advanced economies, especially in Europe, who sought a broader range of assets but continued to place a high value on perceived safety. Although Europe as a whole was not running a current account surplus during this period, unlike the GSG economies, it financed purchases of U.S. securities, including MBS, through issuance of a range of external

liabilities. As the composition of home mortgages became increasingly skewed toward subprime 
and other risky loans, the U.S. financial services industry developed techniques to transform these loans into the apparently safe, AAA-rated securities demanded by investors at home and abroad. The subsequent bursting of the housing bubble and recognition that many of these securities were far riskier than had previously been recognized helped to trigger the financial crisis.

Looking back on the crisis, the United States, like some emerging-market nations during the 1990s, has learned that the interaction of strong capital inflows and weaknesses in the domestic financial system can produce unintended and devastating results. The appropriate response is not to try to reverse financial globalization, which has conferred considerable benefits overall. Rather, the United States must continue to work with its international partners to improve private-sector financial practices and strengthen financial regulation, including macroprudential oversight. The ultimate objective should be to be able to manage even very large flows of domestic and international financial capital in ways that are both productive and conducive to financial stability. 


\section{References}

Acharya, Viral V. and Philipp Schnabl (2010). “Do Global Banks Spread Global Imbalances? Asset-Backed Commercial Paper during the Financial Crisis of 2007-09," IMF Economic Review, vol. 58 (1), pp. 37-73.

Arteta, Carlos, Mark Carey, Ricardo Correa, and Jason Kotter (2009). "Revenge of the Steamroller: ABCP as a Window on Risk Choices," unpublished working paper, Board of Governors of the Federal Reserve System, Division of International Finance, May 15.

Beltran, Daniel, Maxwell Kretchmer, Jaime Marquez, and Charles Thomas (2010). "U.S. Treasury Yields and Foreign Holdings of U.S. Securities: An Interim Report,” unpublished working paper, Board of Governors of the Federal Reserve System, Division of International Finance, February.

Bernanke, Ben S. (2005). “The Global Saving Glut and the U.S. Current Account Deficit.” speech delivered at the Sandridge Lecture, Virginia Association of Economists, Richmond, Va., March 10.

Bernanke, Ben S. (2007). “Global Imbalances: Recent Developments and Prospects,” speech delivered at the Bundesbank Lecture, Berlin, Germany, September 11.

Bernanke, Ben S. (2010). “Causes of the Recent Financial and Economic Crisis,” statement before the Financial Crisis Inquiry Commission, September 2.

Bernanke, Ben S., Vincent R. Reinhart, and Brian. P. Sack (2004). “Monetary Policy Alternatives at the Zero Bound: An Empirical Assessment," Brookings Papers on Economic Activity, vol. 2:2004. Washington: Brookings Institution Press, pp. 1-100.

Bertaut, Carol (2008). “Assessing the Potential for Further Foreign Demand for U.S. Assets: Has Financing U.S. Current Account Deficits Made Foreign Investors Overweight in U.S. Securities?” Board of Governors of the Federal Reserve System, International Finance Discussion Papers 950. Washington: Board of Governors of the Federal Reserve System, October.

Bertaut, Carol, Laurie DeMarco, Steven Kamin, and Ralph Tryon (2010). "ABS Inflows to the U.S. and the Global Financial Crisis,” unpublished working paper, Board of Governors of the Federal Reserve System, International Finance, October.

Blanchard, Olivier, Francesco Giavazzi, and Filipa Sa (2005). “The U.S. Current Account and the Dollar,” NBER Working Paper Series 11137. Cambridge, Mass.: National Bureau of Economic Research, February.

Brender, Anton, and Florence Pisani (2010). Global Imbalances and the Collapse of Globalised Finance. Brussels: Centre for European Policy Studies. 
Caballero, Ricardo J., Emmanuel Farhi, and Pierre-Olivier Gourinchas (2008). "An Equilibrium Model of 'Global Imbalances' and Low Interest Rates,” American Economic Review, vol. 98 (1), pp. 358-93.

Caballero, Ricardo, and Arvind Krishnamurthy (2009). "Global Imbalances and Financial Fragility,” American Economic Review: Papers \& Proceedings, vol. 99 (May), pp. 58488.

Clarida, Richard H. (2005). “Japan, China, and the U.S. Current Account Deficit,” Cato Journal, vol. 25 (1), pp. 111-14.

Cooper, Richard N. (2005). "Living with Global Imbalances: A Contrarian View,” Peterson Institute for International Economics Policy Brief PB05-3. Washington: Peterson Institute for International Economics, November.

Coval, Joshua D., Jakub W. Jurek, and Erik Stafford (2008). "The Economics of Structured Finance,” Harvard Business School Finance Working Paper No. 09-060. Boston, Mass.: Harvard Business School, October.

Dokko, Jane, Brian Doyle, Michael T. Kiley, Jinill Kim, Shane Sherlund, Jae Sim, and Skander Van den Heuvel (2009). "Monetary Policy and the Housing Bubble," Finance and Economics Discussion Series 2009-49. Washington: Board of Governors of the Federal Reserve System, December.

Gerardi, Kristopher, Andreas Lehnert, Shane Sherlund, and Paul Willen (2008). "Making Sense of the Subprime Crises," in Brookings Papers on Economic Activity, vol. 2 (Fall). Washington: Brookings Institution Press, pp. 69-145.

Gorton, Gary B. (2008). “The Panic of 2007,” in Maintaining Stability in a Changing Financial System, proceedings of the 2008 Economic Policy Symposium. Kansas City: Federal Reserve Bank of Kansas City, pp. 131-262.

Gorton, Gary B. (2009). "Information, Liquidity, and the (Ongoing) Panic of 2007,” American Economic Review, Papers and Proceedings, vol. 99 (May), pp. 567-72.

Greenspan, Alan (2005). “Monetary Policy Report to the Congress," statement before the Committee on Banking, Housing, and Urban Affairs, U.S. Senate, February 16.

Gruber, Joseph, and Steven Kamin (2009). "Do Differences in Financial Development Explain the Global Pattern of Current Account Imbalances?” Review of International Economics, vol. 17 (4), pp. 667-88.

Hubbard, R. Glenn. (2005). “A Paradox of Interest,” Wall Street Journal, June 23. 
Jagannathan, Ravi, Mudit Kapoor, and Ernst Schaumburg (2009). "Why Are We in a Recession? The Financial Crisis Is the Symptom Not the Disease!” NBER Working Paper Series 15404. Cambridge, Mass.: National Bureau of Economic Research, October.

Linde, Jesper, Robert Martin, and Robert Vigfusson (2010). "Capital Flows, Intermediation, and Liquidity: A Recipe for Crisis?” unpublished working paper, Board of Governors of the Federal Reserve System, Division of International Finance, December.

Mayer, Christopher, Karen Pence, and Shane M. Sherlund (2009). “The Rise in Mortgage Defaults,” Journal of Economic Perspectives, vol. 23 (Winter), pp. 27-50.

McGuire, Patrick, and Goetz von Peter (2009). “The US Dollar Shortage in Global Banking,” BIS Quarterly Review, March, pp. 47-63.

Mendoza, Enrique G., Vincenzo Quadrini, and Jose-Victor Rios-Rull (2007). “Financial Integration, Financial Deepness, and Global Imbalances,” NBER Working Paper Series 12909. Cambridge, Mass.: National Bureau of Economic Research, February.

Nadauld, Taylor D., and Shane M. Sherlund (2009). “The Role of the Securitization Process in the Expansion of Subprime Credit,” Finance and Economics Discussion Series 2009-28. Washington: Board of Governors of the Federal Reserve System, April.

Rudebusch, Glenn D., Eric T. Swanson, and Tao Wu (2006). “The Bond Yield 'Conundrum' from a Macro-Finance Perspective,” Monetary and Economic Studies (Special edition), Bank of Japan, vol. 24 (S1, December), pp. 83-128.

Warnock, Frank, and Veronica Warnock (2009). “International Capital Flows and U.S. Interest Rates,” Journal of International Money and Finance, vol. 28 (October), pp. 903-19. 
Table 1

U.S. securities outstanding, 2003 and 2007

Billions of dollars

\begin{tabular}{|c|c|c|c|c|c|c|c|c|}
\hline & $\begin{array}{c}\text { Total } \\
\text { Securities } \\
\text { (1) }\end{array}$ & $\begin{array}{c}\text { Treasury } \\
\text { securities } \\
\text { (2) }\end{array}$ & $\begin{array}{c}\text { Agency } \\
\text { debt } \\
\text { (3) }\end{array}$ & $\begin{array}{c}\text { Corporate } \\
\text { AAA } \\
\text { (4) }\end{array}$ & $\begin{array}{c}\text { ABS/MBS } \\
\text { AAA } \\
\text { (5) }\end{array}$ & $\begin{array}{c}\text { Corporate } \\
\text { Non-AAA } \\
\text { (6) }\end{array}$ & $\begin{array}{c}\text { ABS/MBS } \\
\text { Non-AAA } \\
(7)\end{array}$ & $\begin{array}{c}\text { Equity } \\
\text { (8) }\end{array}$ \\
\hline 1. Total U.S. securities outstanding, 2003 & 29,757 & 3,342 & 5,969 & 393 & 1,439 & 4,093 & 254 & 14,266 \\
\hline 2. Held by foreign investors & 5,239 & 1,477 & 571 & 157 & 162 & 1,003 & 29 & 1,839 \\
\hline 3. Of which: Europe & 2,182 & 345 & 192 & 74 & 86 & 496 & 15 & 974 \\
\hline 4. Of which: GSGs & 870 & 449 & 198 & 5 & 11 & 33 & 2 & 172 \\
\hline 5. Held by U.S. residents & 24,518 & 1,864 & 5,398 & 236 & 1,277 & 3,090 & 225 & 12,427 \\
\hline 6. Total U.S. securities outstanding, 2007 & 40,169 & 4,113 & 6,786 & 425 & 3,154 & 5,286 & 458 & 19,947 \\
\hline 7. Held by foreign investors & 9,796 & 2,384 & 1,384 & 214 & 788 & 1,679 & 114 & 3,232 \\
\hline 8. Of which: Europe & 3,978 & 399 & 308 & 126 & 487 & 993 & 71 & 1,594 \\
\hline 9. Of which: GSGs & 2,082 & 905 & 656 & 9 & 44 & 72 & 6 & 389 \\
\hline 10. Held by U.S. residents & 30,373 & 1,729 & 5,402 & 210 & 2,366 & 3,607 & 344 & 16,715 \\
\hline \multicolumn{9}{|l|}{ Memo: } \\
\hline change in value outstanding (\%) & 43.8 & 117.5 & 99.6 & 182.0 & 36.5 & 56.7 & 42.0 & 24.5 \\
\hline
\end{tabular}

Note: Changes in holdings and securities outstanding include valuation changes. Global saving glut (GSG) countries include Asia (excluding Japan) and the Middle East. ABS: asset-backed securities (excluding MBS); MBS: mortgage-backed securities.

Source: Staff estimates based on Flow of Funds and Treasury International Capital system. 
Figure 1

Federal funds and 10-year U.S. Treasury rates

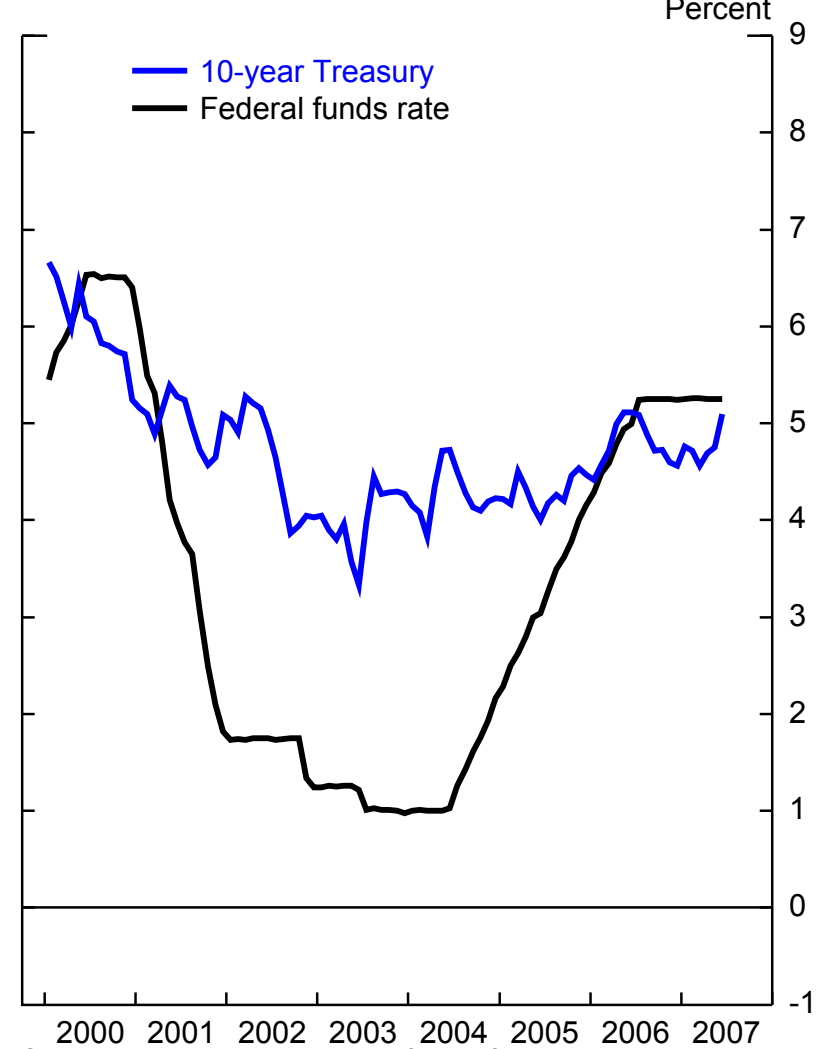

10-year U.S. Treasury and 30-year U.S. fixed mortgage rates, and spread

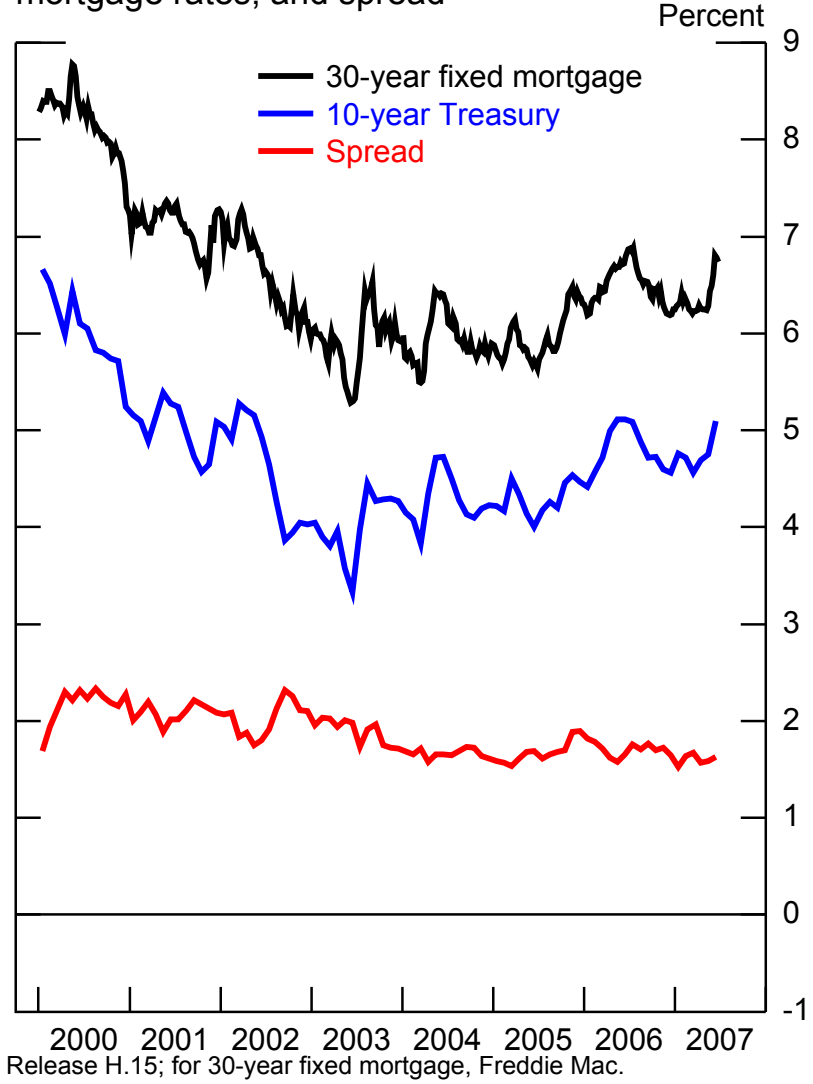


Figure 2

Current account surpluses and certain financial acquisitions of GSG regions, 2003-2007*

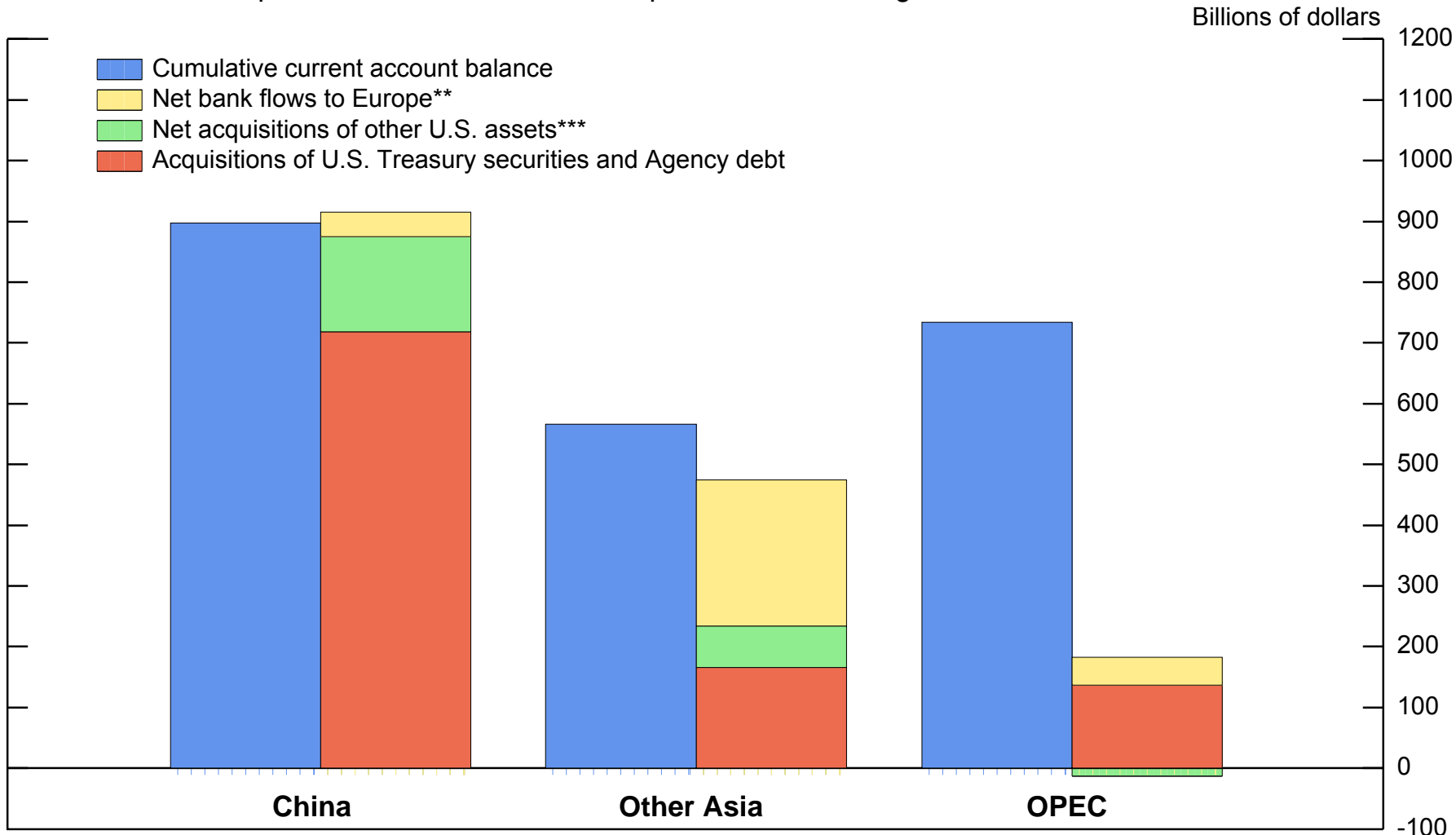

*Acquisitions of European and other non-U.S. securities by emerging Asia and OPEC are unavailable. **Bank flows to Europe calculated from BIS data.

${ }^{* * *}$ Other U.S. assets comprises corporate securities, bank assets, and other miscellaneous assets included in the Financial Accounts. Note: GSG: global saving glut.

Source: For current account balance, Haver Analytics and BEA; for balance of payments accounts, staff estimates based on Treasury International Capital system and Bank for International Settlements banking data. 
Figure 3

\section{U.S. securities outstanding \\ Total}
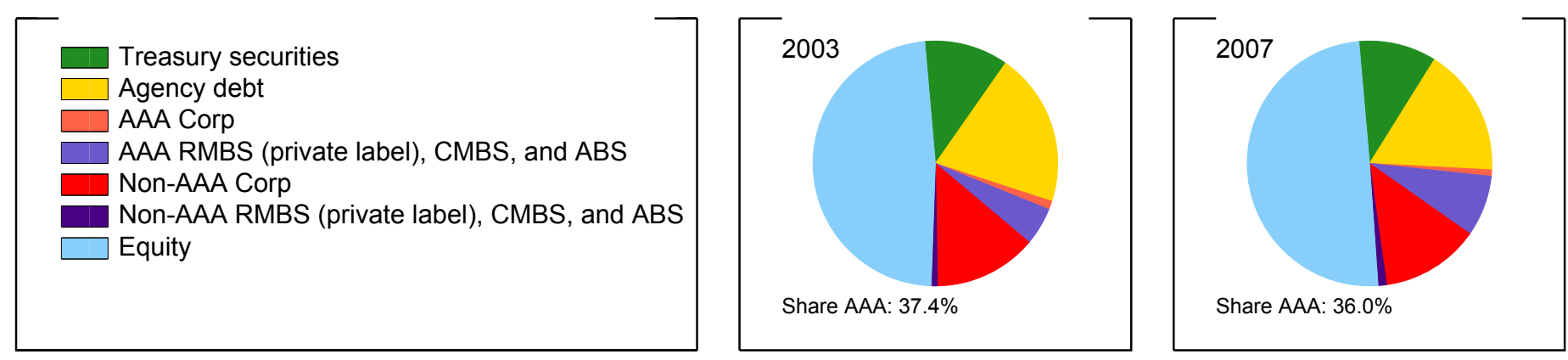

\section{Held by global saving glut countries}
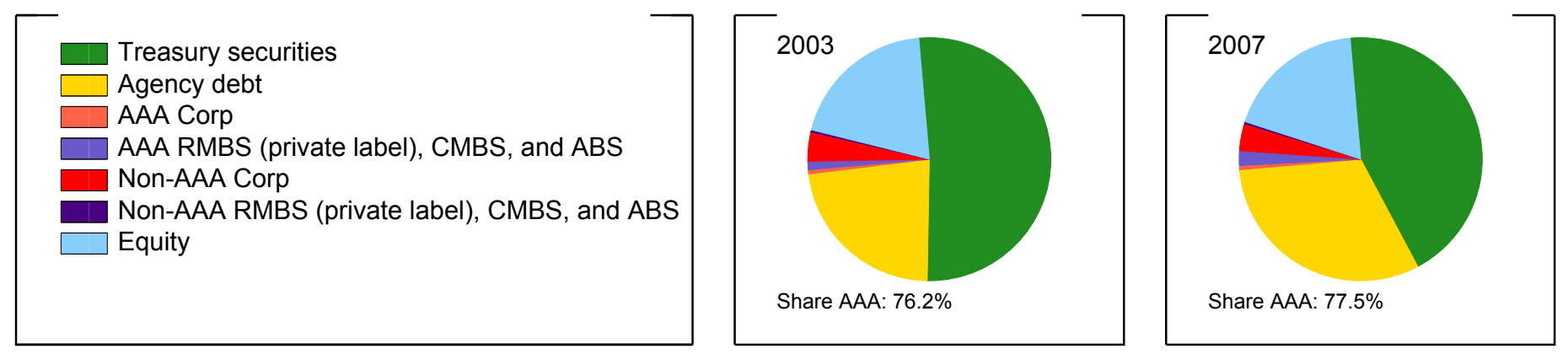

\section{Held by Europe}

Treasury securities

Agency debt

AAA Corp

AAA RMBS (private label), CMBS, and ABS

Non-AAA Corp

Non-AAA RMBS (private label), CMBS, and ABS

Equity
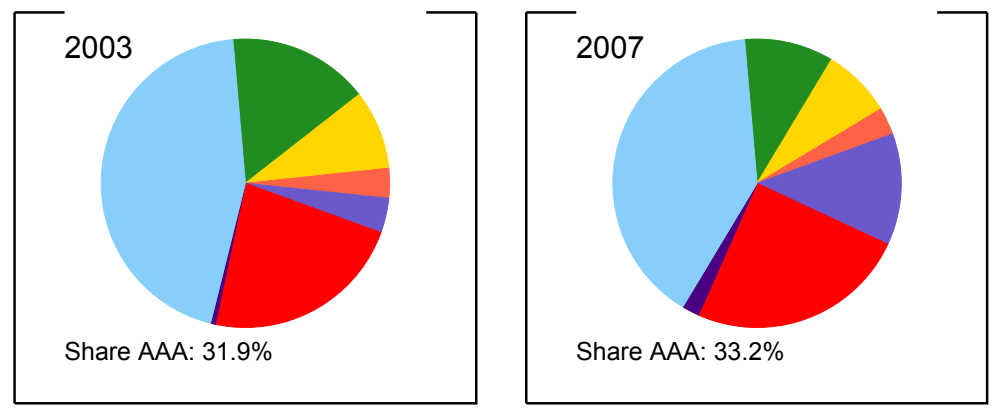

\section{Held by U.S. residents}

Treasury securities

Agency debt

AAA Corp

AAA RMBS (private label), CMBS, and ABS

Non-AAA Corp

Non-AAA RMBS (private label), CMBS, and ABS

Equity
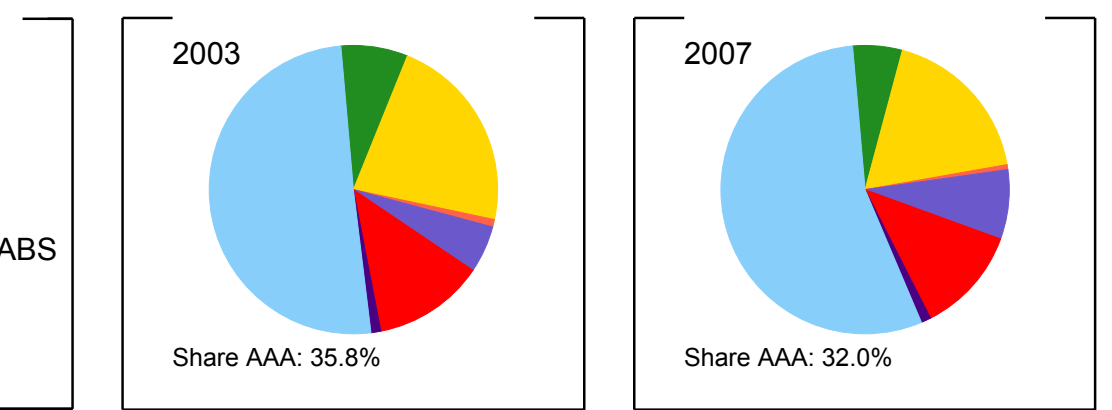

Note: RMBS: residential mortgage-backed securities; CMBS: commercial mortgage-backed securities; ABS: asset-backed securities other than RMBS and CMBS. Source: Staff estimates based on Flow of Funds and Treasury International Capital system data. 
Figure 4

Inflows to U.S. AAA-rated securities

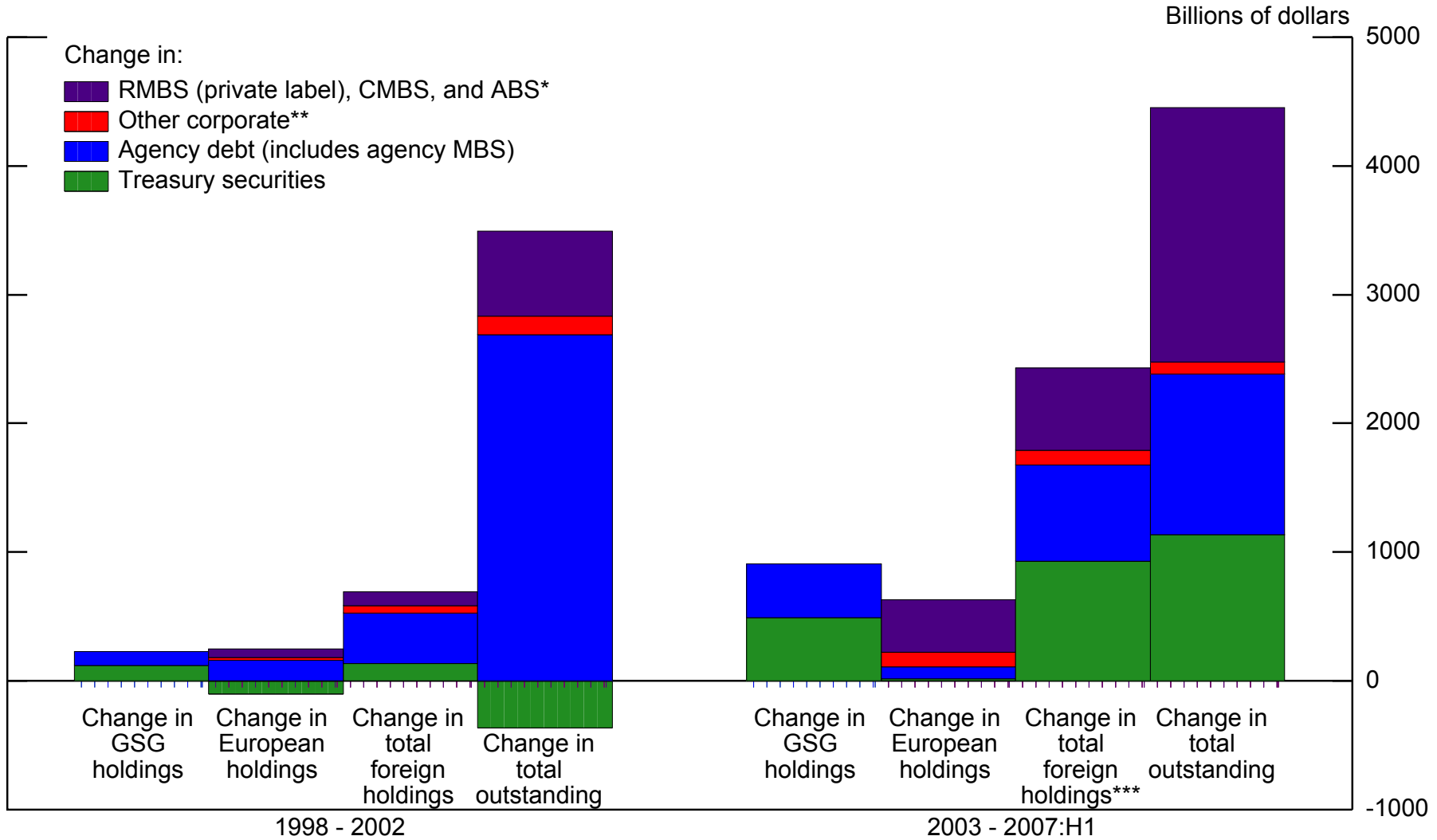

*We estimated the change in foreign holdings (both total foreign holdings and Europe's holdings) of AAA RMBS, CMBS, and ABS by multiplying the change in foreign holdings of all asset-backed securities by the share of such securities outstanding that are estimated to be rated AAA during the relevant period.

**We estimated the change in foreign holdings (both total foreign holdings and Europe's holdings) of other AAA corporate debt securities by multiplying the change in foreign holdings of all securities by a weighted share of such securities outstanding that were rated AAA during the relevant period. For both periods, the weighted share averages the shares of financial and non-financial debt securities that were rated AAA. For 1998 to 2002, the weights are determined by the growth in financial debt securities outstanding relative to non-financial debt securities. For 2003 to 2007 , when more detailed data on foreign holdings are available, the weights are determined by the growth in foreign holdings of financial debt securities relative to non-financial debt securities.

$* * \star$ Of the U.S. AAA inflows not accounted for by GSG countries and Europe, Japan purchased about $\$ 240$ billion of Treasuries and $\$ 130$ billion of Agencies, and Caribbean offshore centers purchased about $\$ 55$ billion of Agencies and about $\$ 160$ billion of AAA RMBS, CMBS, and ABS.

Note: GSG: global saving glut; RMBS: residential mortgage-backed securities; CMBS: commercial mortgage-backed securities; ABS: asset-backed securities other than RMBS and CMBS.

Source: Staff estimates based on Flow of Funds, Treasury International Capital system, and Dealogic data. 
Figure 5

European inflows to U.S. securities, by type

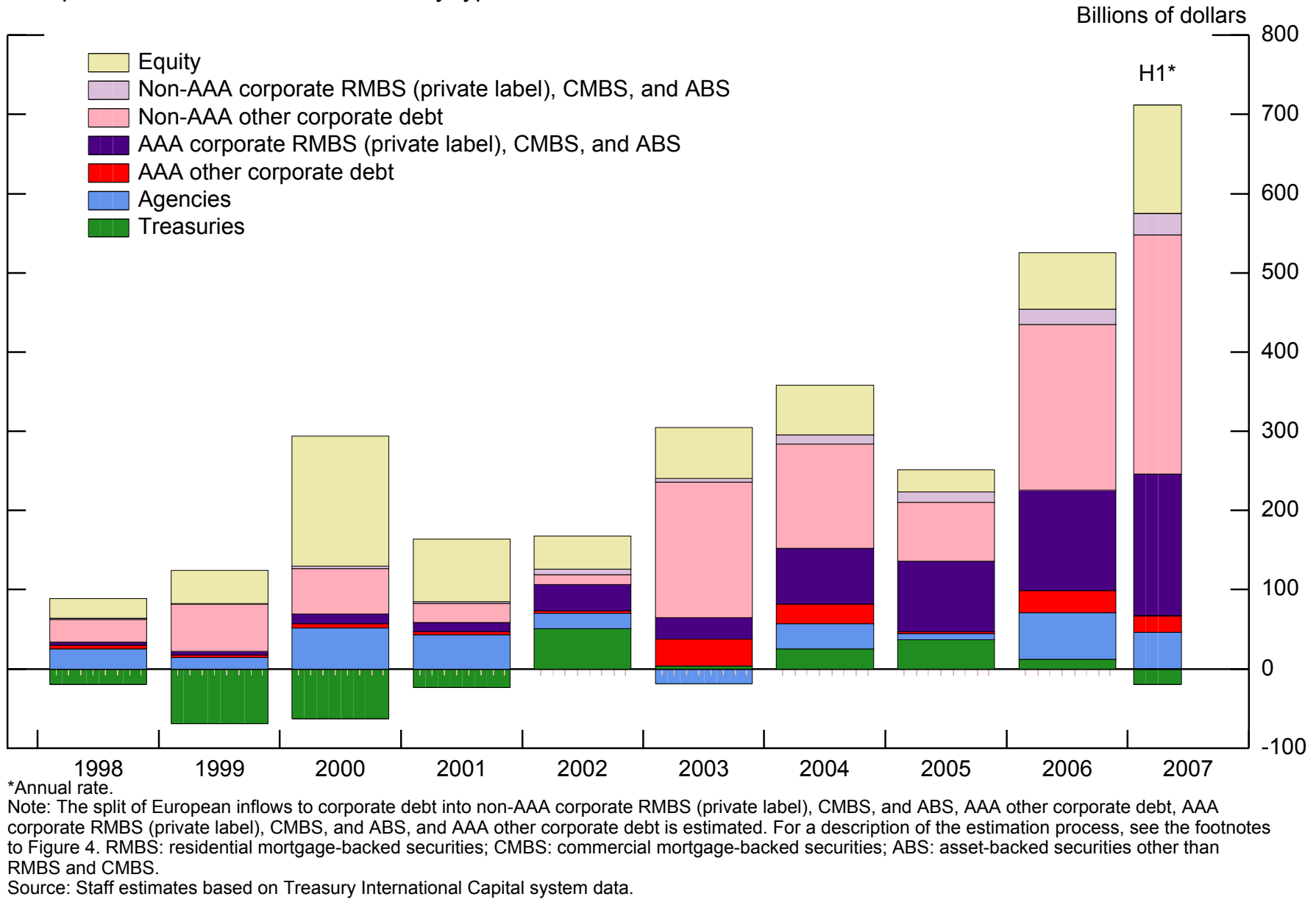


Figure 6

Europe's international gross claims and liabilities: 2003 to 2007

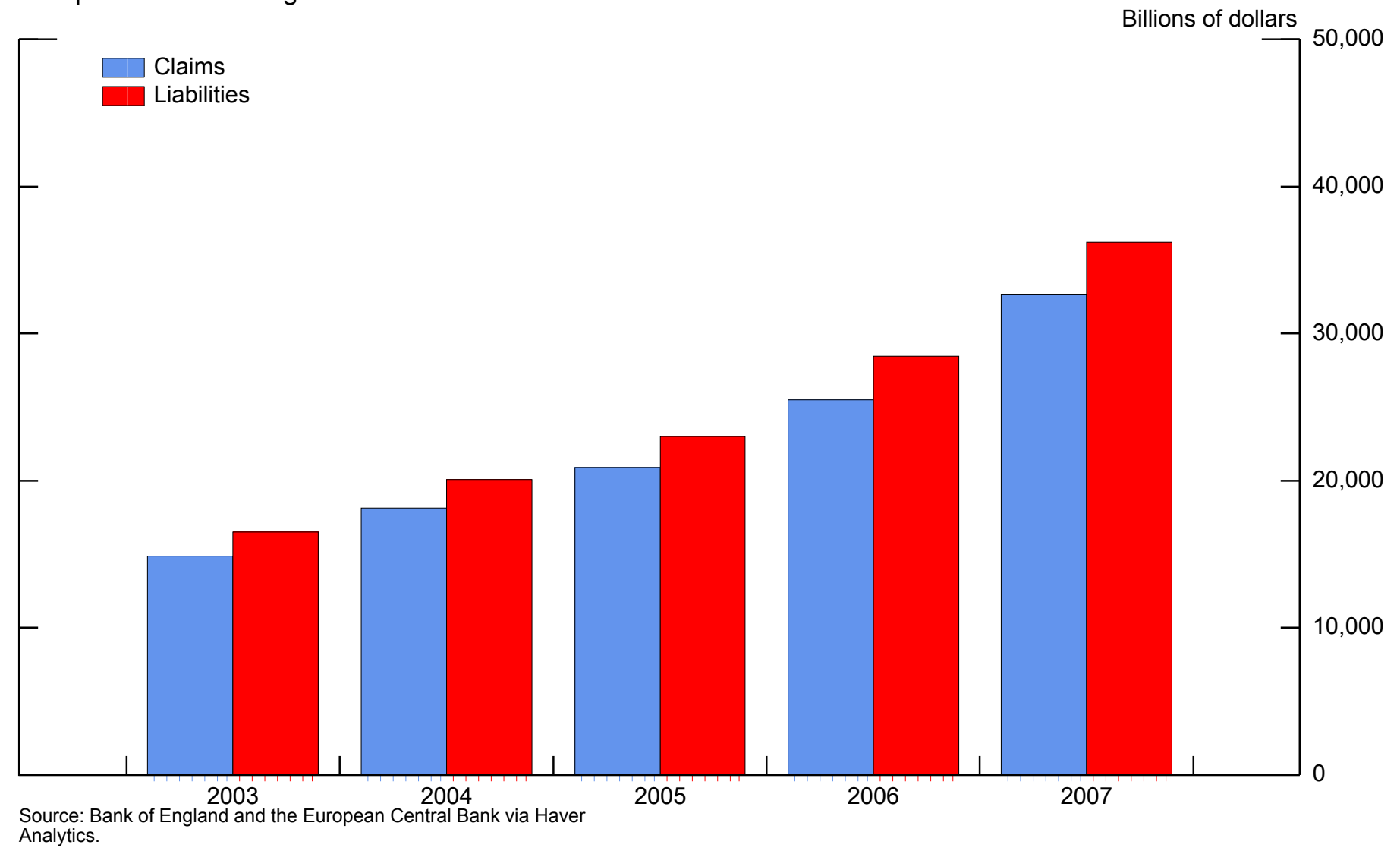




\section{Figure 7}

\section{Cumulated European cross-border financial flows*}

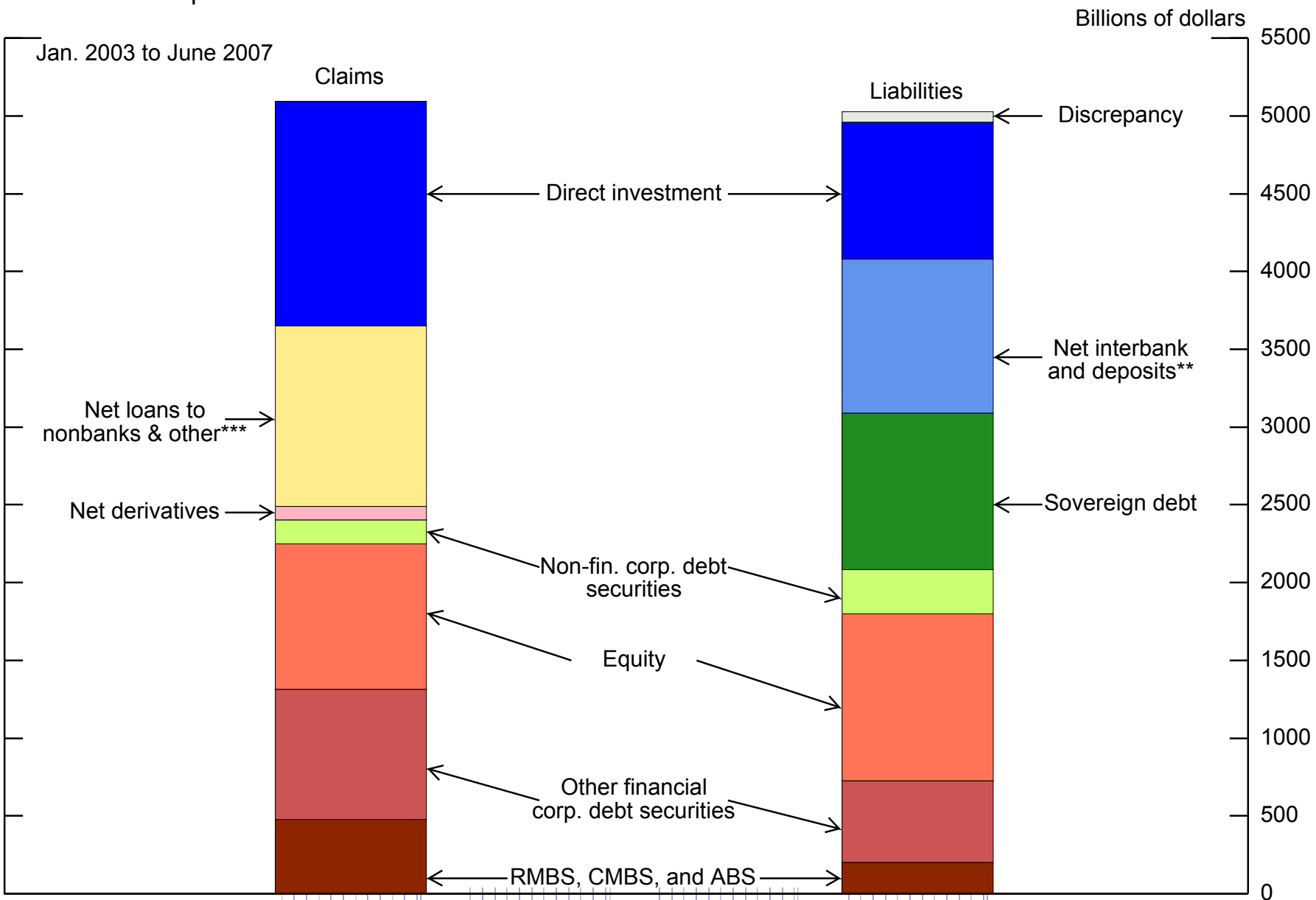

*Flows of euro area and the United Kingdom with the rest of the world, net of intra-Europe flows.

**Estimates of interbank flows and deposits from nonbank residents are based on the banking component of 'Other Investment' in the euro area and U.K. Financial Accounts, and Bank for International Settlements data.

${ }^{* *}$ Components of 'Other Investment' in the euro area and U.K. Financial Accounts that are not identified as interbank or deposits from nonbank residents, primarily loans to nonbank firms and transactions of brokers.

Note: RMBS: residential mortgage-backed securities; CMBS: commercial mortgage-backed securities; ABS: asset-backed securities other than RMBS and CMBS.

Source: Federal Reserve Board staff estimates. 
Value of mortgages outstanding

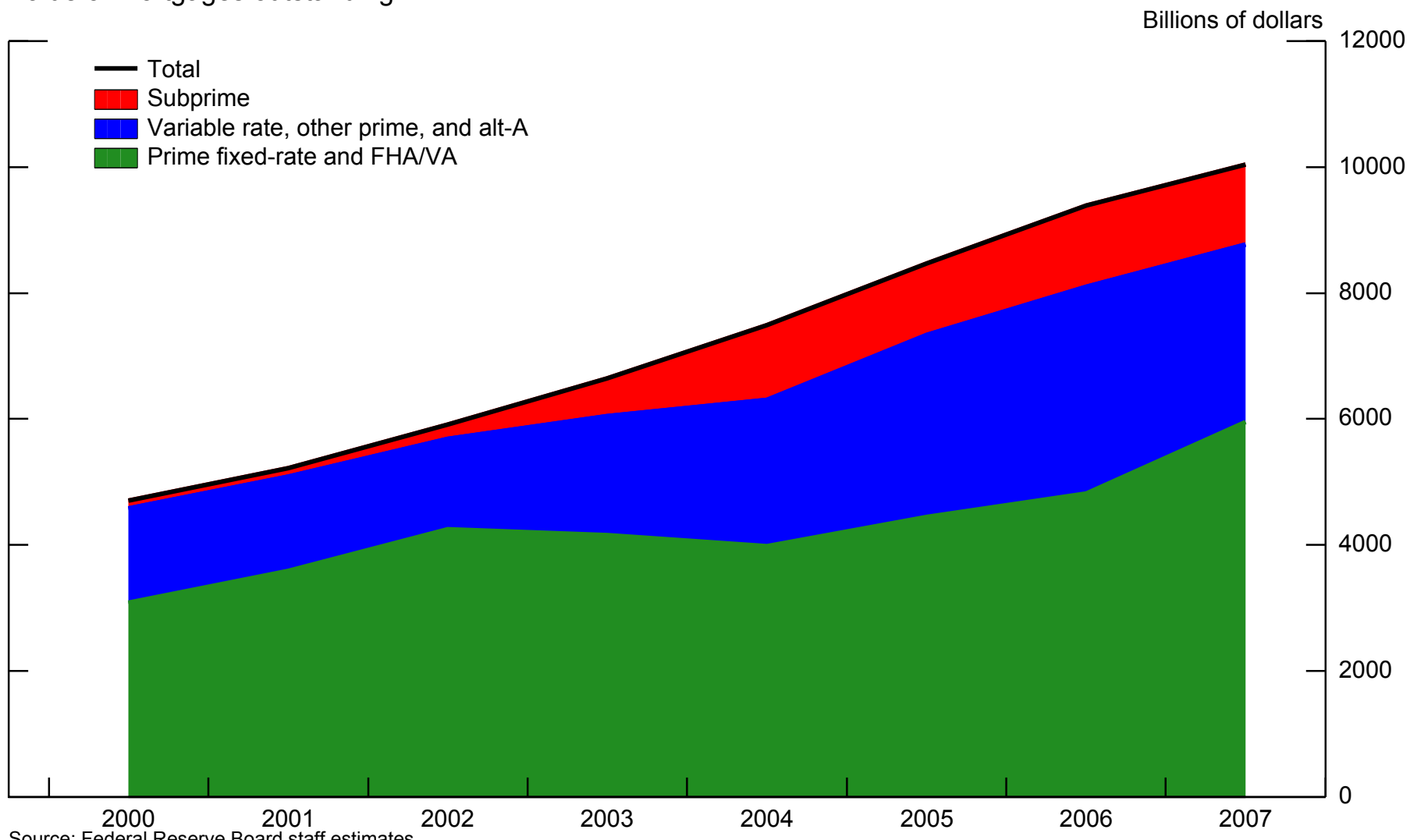

Source: Federal Reserve Board staff estimates.

RMBS, CMBS, and ABS outstanding, by rating

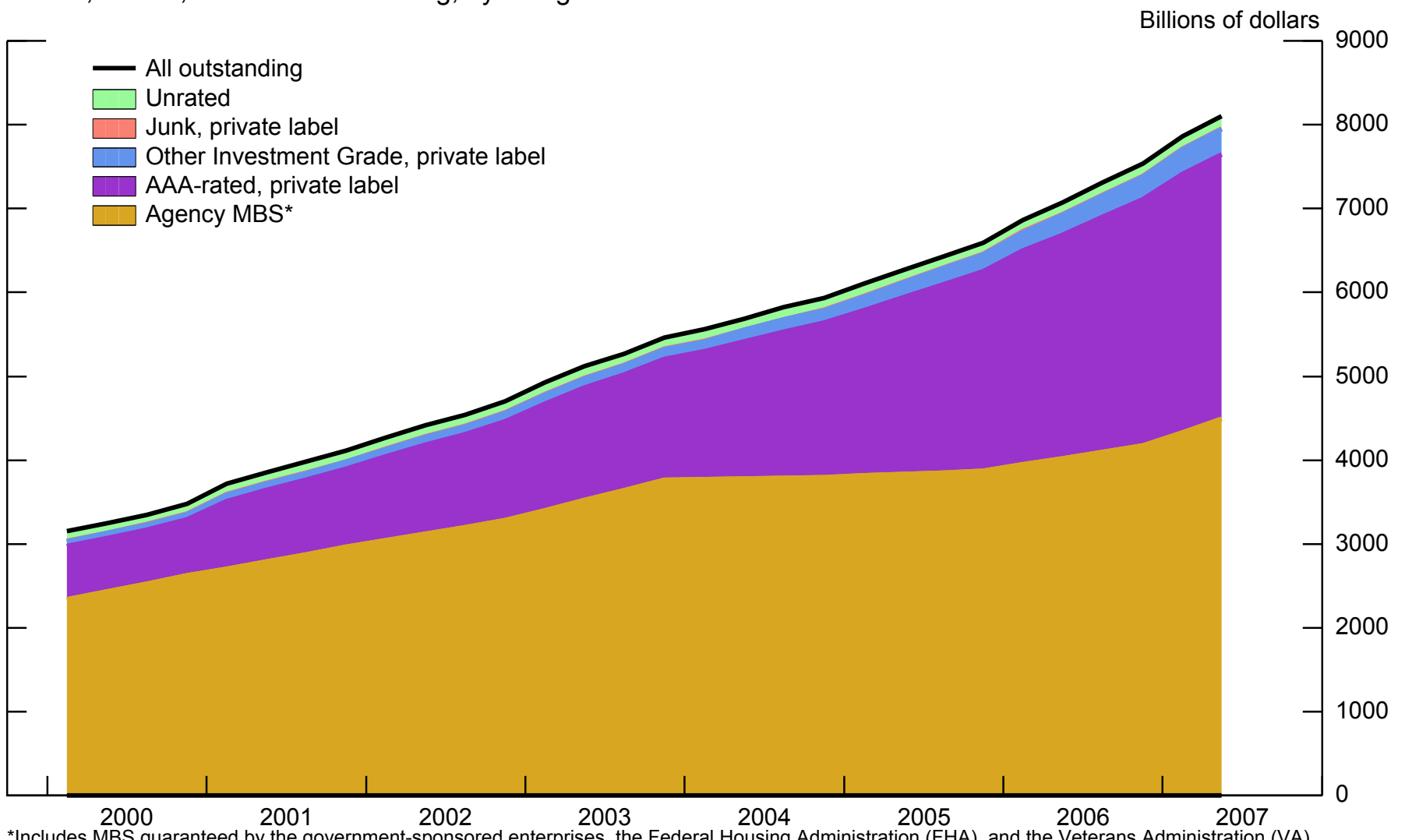


Figure 9

Share of bonds outstanding rated AAA, by type

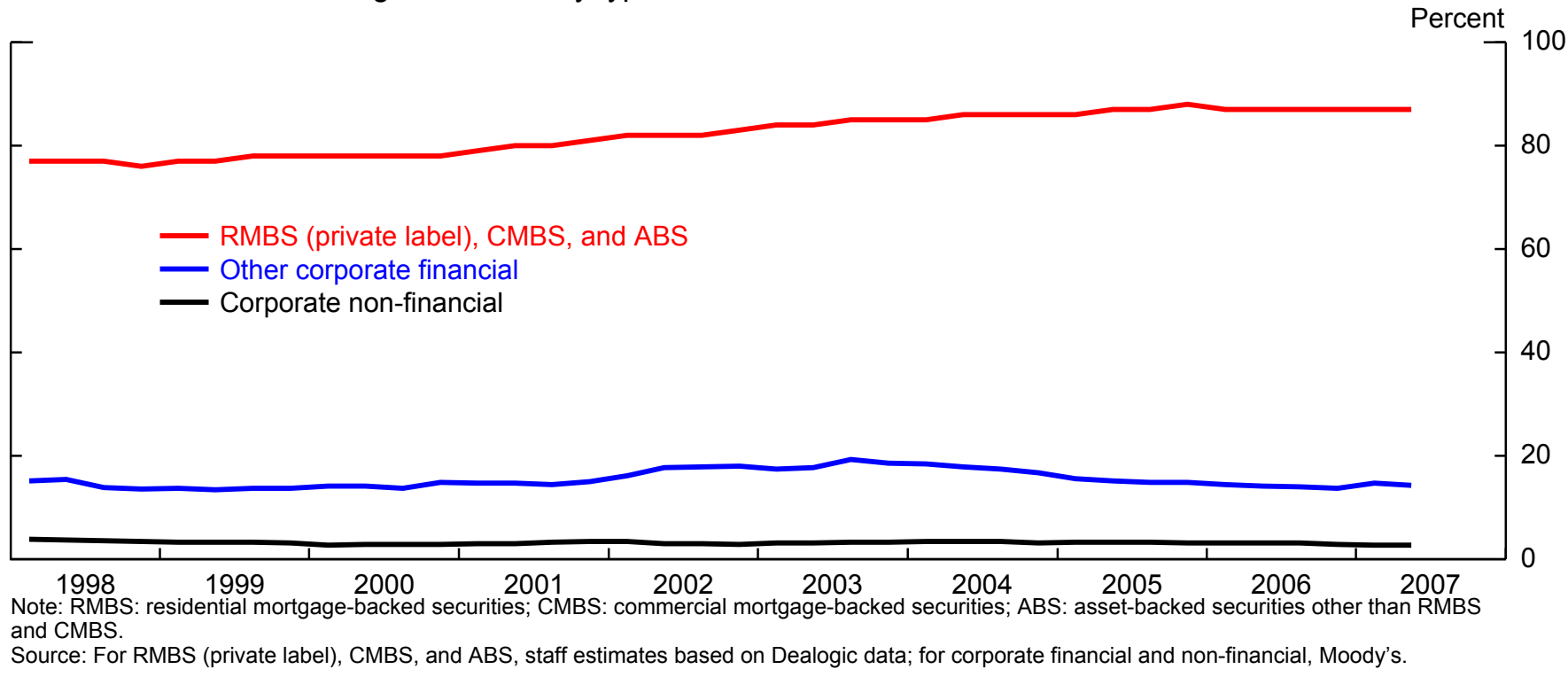


Figure 10

Subprime adjustable-rate mortgage (ARM) issuance

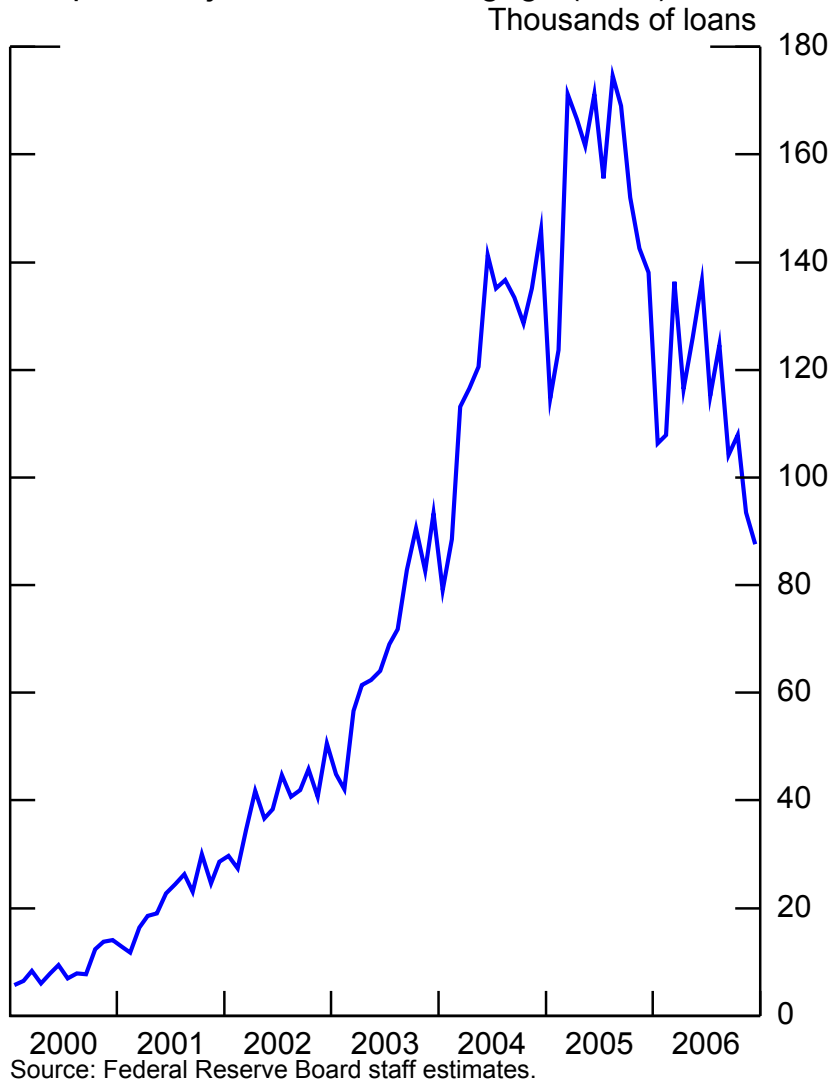

Rates on subprime and conforming adjustable-rate mortgages (ARMs)

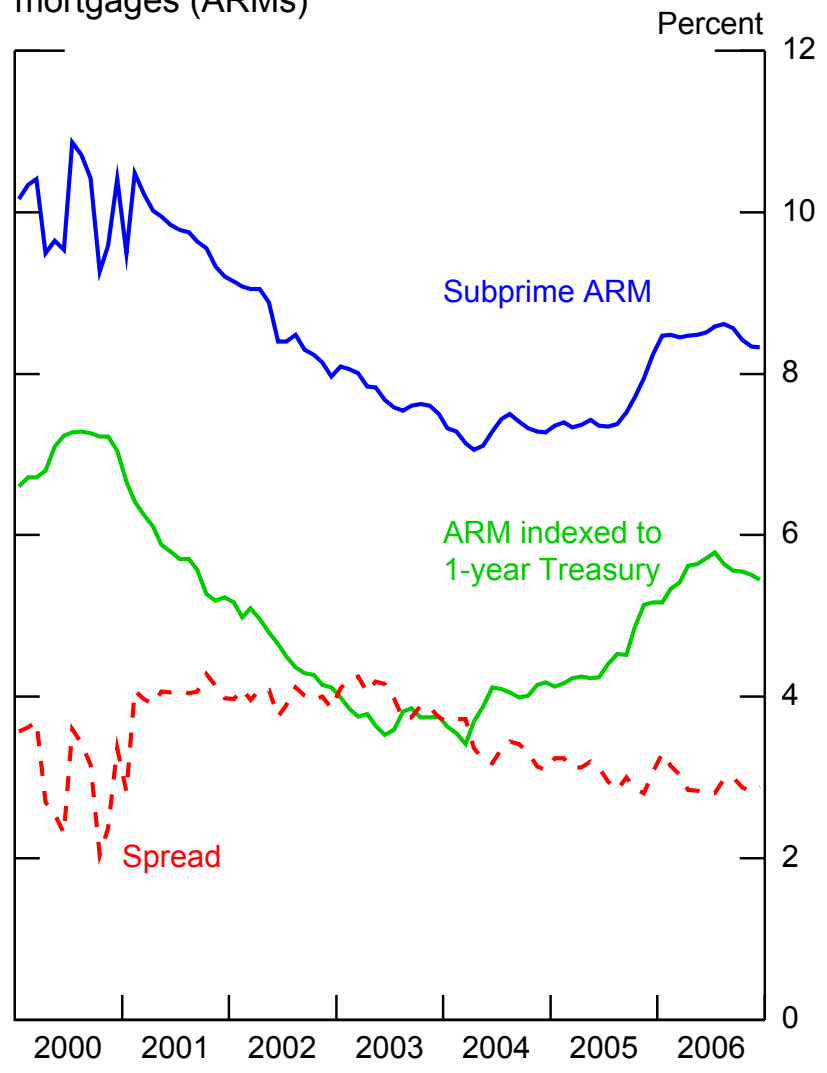




\section{Data appendix}

\section{Sources for total amounts of U.S. securities outstanding}

Total amounts of U.S. securities outstanding are taken from the U.S. Flow of Funds accounts levels (L) tables, available on the Federal Reserve Board website at this link: http://www.federalreserve.gov/releases/z1/default.htm

Total Treasury securities: Table L.2, line 4

Total Agency securities: Table L.3, lines 3 plus 4

Total financial corporate debt: Table L.3, line 5

Total non-financial corporate: Table L.2, lines 4, 6, and 7

Total private-label ABS ${ }^{1}$ : Table L.3, line 19

\section{Estimates of the amounts outstanding of securities rated AAA}

Although we use the U.S. Flow of Funds data to obtain comprehensive measures of securities outstanding, these data do not include the credit ratings of the securities. We estimate the shares of securities that are AAA-rated using commercial sources, and apply these shares to the Flow of Funds amounts.

2a. Non-ABS debt securities-amounts outstanding rated $A A A$

We derive estimates of the AAA-rated fraction of corporate debt securities outstanding other than ABS from Moody's Default Risk Service (DRS) database. We compute these shares separately for financial and non-financial corporate debt, and apply the respective shares to the total amounts of corporate financial and non-financial debt outstanding from the Flow of Funds. All U.S. Treasuries are rated AAA, as is all Agency debt (including Agency MBS).

\section{2b. ABS securities-amounts outstanding rated $A A A$}

To construct estimates of amounts of U.S. ABS (including RMBS and CMBS) outstanding by rating, we obtained issuance data from Dealogic of all non-Agency ABS tranches issued by U.S. corporations between January 1980 and end-June 2007. We used the fields "Tranche Value \$," “Expected Maturity,” and "Effective Rating (Launch).” In total, we obtained 66,205 tranches.

Because the Dealogic data do not provide us with a given security's credit rating history, we rely on the credit rating at launch and assume that ratings remain constant throughout the life of the security. This assumption may tend to overstate the amount of more highly-rated ABS outstanding, since ratings may be revised downward as more information about underlying assets becomes available. However, we expect any overestimation effect to be limited as our dataset ends in June 2007, predating the major downgrades associated with the financial crisis.

To transform issuance data into estimates of amounts outstanding, we assume securities last as long as their expected maturity life. The expected maturity life adjusts the formal maturity to take into account the probability of early loan repayments; it averages just above five years compared with the average formal maturity of over 24 years. However, only 32 percent of the

\footnotetext{
${ }^{1}$ In this appendix, ABS refers broadly to all asset-backed securities including mortgage-backed securities.
} 
tranches pulled listed an expected maturity date. Accordingly, we calculate average expected maturities each year for those securities containing this information, and we then assign that average maturity to all tranches issued in that year. For tranches priced before 1993, no expected maturity data exist, so we assign the 1993 average to these earlier years.

With estimates of ABS issuance broken down by credit rating and expected maturity in hand, we then aggregate these data to dollar amounts outstanding within each rating category for each quarter. ${ }^{2}$ We convert our constructed series of amounts outstanding by credit rating into shares, and apply these shares to the published Flow of Funds data.

\section{Estimates of foreign holdings and acquisitions of U.S. securities, by country}

Estimated holdings of U.S. securities, broken down by investing country, are based on the annual Treasury International Capital (TIC) surveys of foreign portfolio holdings of U.S. securities. These comprehensive surveys record holdings of U.S. securities by country of holder as of endJune for various years. Survey reports are available on the Treasury website at http://www.treasury.gov/resource-center/data-chart-center/tic/Pages/fpis.aspx

To adjust the end-June securities holdings recorded by the surveys to create estimates as of yearend, we use the Bertaut-Tryon (2007) data, which adjusts for financial center transactions bias and valuation changes. These estimates, as well as a detailed methodology of their construction, are available at: http://www.federalreserve.gov/pubs/ifdp/2007/910/default.htm

For estimates of cumulated foreign net purchases of U.S. securities in Figures 2, 4, and 5, we also use the Bertaut-Tryon data base. ${ }^{3}$ In addition to estimated monthly holdings, this data base provides estimates of monthly changes in holdings, decomposed into identified adjusted net flows (flows are adjusted primarily for repayments of ABS), monthly valuation changes, and the residual "gap" required to reconcile the reported transactions data with the annual survey holdings. We construct cumulated net purchases by country as the sum of the monthly adjusted net flows plus the monthly "gap" to generate estimates of net purchases that are corrected for financial center bias.

We are able to implement the methodology above for purchases of Treasury securities, agency securities, and total corporate debt. We then decompose further our estimates of net purchases of corporate debt by country into purchases of ABS, financial corporate debt, and nonfinancial corporate debt using the relative shares of these types of corporate debt as reported in the detailed data from the annual surveys.

\footnotetext{
${ }^{2}$ Compared to total outstanding amounts in the published Flow of Funds, our estimates of all (non-Agency) ABS outstanding derived from issuance data amount to roughly fifty percent of the published value by the first quarter of 1995, but quickly rise to over two hundred percent by end-1999, and remain roughly that much higher through 2007. A potential explanation for our higher estimate of ABS outstanding than in the Flow of Funds data is that the Dealogic data include CDO tranches while the Flow of Funds data do not.

${ }^{3}$ We use the Bertaut-Tryon data, which corrects for financial center bias in the estimated net purchases by country, instead of the as-reported TIC net purchases data available on the Treasury website because the financial center distortions are particularly important for the countries we consider.
} 


\section{Estimates of foreign holdings of corporate debt securities rated AAA}

\section{4a. Non-ABS corporate debt securities rated AAA}

Although the detailed survey data that underlie our estimates of foreign holdings of corporate debt allow us to distinguish financial from non-financial debt for 2003-2007, they do not provide us with credit rating information. We assume that the shares of financial and non-financial corporate debt held by foreign investors that are rated AAA are proportionate to those for all U.S. financial and non-financial corporate debt outstanding. However, because foreign investors in general and European investors in particular hold a larger share of their total U.S. corporate debt portfolio in financial debt - which in turn has a larger share rated AAA - our estimates show foreign investors holding a larger overall share of their U.S. corporate debt portfolio in AAA-rated securities than is true of U.S. corporate debt outstanding.

Detail on the breakdown of foreign holdings of U.S. corporate debt between financial and nonfinancial issuers is not available for the 1998-2002 period. For each year of the period, we assume that this breakdown is the same as that for all U.S. corporate debt outstanding. As above, we also assume that the AAA-rated shares of each type of corporate debt held by foreign investors are proportionate to the AAA-rated shares of financial and non-financial corporate debt outstanding.

4b. Corporate ABS securities rated AAA

As with non-ABS corporate debt securities, our detailed survey data do not provide us with credit ratings of the individual ABS held by foreign investors. We assume that when foreigners invest in U.S. ABS, the share they hold in AAA-rated ABS is proportional to the AAA-rated share of ABS outstanding.

\section{European cross-border financial flows shown in Figure 7}

We proxy Europe's cross-border financial flows over this period by summing the flows for the euro area and the U.K., using their balance of payments (BOP) and international investment positions (IIP) data. For the euro area, these are available in the Monthly Bulletin table 7.3 and related dataset: http://sdw.ecb.europa.eu/reports.do?node $=100000210$. For the United Kingdom, these are available in the annual Pink Book and associated data set:

http://www.statistics.gov.uk/statbase/product.asp?vlnk=1140. These sources provide data on three types of cross-border investment: direct investment, portfolio investment (equity and debt securities), and other investment (banking and other transactions). Summing the flows of the euro area and the U.K. would overstate their combined net flows with the rest of the world because it would include their flows to each other. To correct this, we subtract the flows between the two economies, primarily using the geographical breakdowns of their IIPs. ${ }^{4}$ All flows and positions are converted to U.S. dollars on a quarterly basis.

Importantly, these sources do not disaggregate flows of debt securities by type, distinctions that are important to understanding the build-up of risk before the crisis. They also do not separate "other investment" into categories that are useful for thinking about the crisis, such as interbank

\footnotetext{
${ }^{4}$ We use separate geographical breakdowns for the three broad types of investment; for "other investment," we are able to estimate flows separately for bank and non-bank positions.
} 
transactions versus transactions with non-banks. Accordingly, we disaggregate these categories using a variety of other sources; we provide a brief overview below of our methodology. Further detail on our estimation procedures is available upon request.

\section{Disaggregating debt securities}

We disaggregate Europe's external claims and liabilities in the form of debt securities into ABS, other financial corporate, non-financial corporate, and sovereign debt using different methods for claims and liabilities because of differences in data availability. For claims, we start with Europe's acquisitions of U.S. debt securities of each type, which are available from the Treasury International Capital (TIC) system. For Europe's claims on other countries besides the United States, we draw on the country distribution of euro area and U.K. claims in the form of debt securities found in the IMF's Coordinated Portfolio Investment Survey (CPIS), and assume that European investors acquired a similar portfolio of debt securities from each country as U.S. investors acquired from that country (again using TIC data to estimate the composition of U.S. acquisitions).

For external liabilities, the U.K. data differentiate between sovereign debt, bank debt and nonbank debt. We assume that, in addition to bank debt, one-quarter of U.K. non-bank debt is issued by financial firms and the remainder is by non-financial firms. For the euro area, data on external liabilities in the form of sovereign debt are available for recent years; we estimate foreign acquisitions of sovereign debt for the earlier period based on euro area sovereign debt issuance. ${ }^{5}$ Corporate debt liabilities of the euro area (excluding ABS) are split into financial and non-financial categories by assuming investors from all countries acquired a portfolio of European corporate debt similar to that acquired by U.S. investors (based on TIC data). Finally, our estimates of foreign holdings of European ABS, combining the euro area and the United Kingdom, are primarily based on data from the European Securitization Forum (ESF) on gross issuance of ABS and primary distribution of ABS abroad; as the resulting estimates are particularly tenuous, the U.S. acquisitions of European ABS (shown in the TIC data) provide a lower bound.

\section{Disaggregating Banking and Other Transactions}

In Figure 7, we present two broad categories of banking and other transactions. The first is "net interbank transactions and deposits," which represents the net of external claims and liabilities of the following three types of transactions: 1) interbank transactions; 2) repurchase agreements (repos) between or among banks and other financial firms, such as securities dealers; and 3) deposits by non-bank residents (where deposits abroad by European residents are a claim and deposits in European banks from non-bank foreigners are a liability). The second category is "net loans to non-banks and other," which represents the net of external claims and liabilities of the following two types of transactions: 1) loans to non-banks (where loans to non-banks abroad - made either by banks or non-bank firms - are a claim and loans from abroad to European non-banks are a liability); and 2) miscellaneous other (such as increased currency liabilities of the ECB to foreigners).

\footnotetext{
${ }^{5}$ We adjust for the fact that foreign acquisitions of euro area sovereign debt tended to grow faster than sovereign debt issuance and confirmed our figures with acquisitions of euro-denominated reserve assets in the Currency Composition of Official Foreign Exchange Reserves (COFER) data.
} 
Of the five transaction types identified in the above paragraph, only two, deposits by non-bank residents and miscellaneous other, are clearly identified in the BOP or IIP data. The amounts for the other types are estimated using several sources, including primarily: 1) additional breakdowns that are provided in the euro area and U.K. BOP data; 2) BIS locational data, which splits banks' cross-border positions into those with other banks and those with non-banks; and 3) aggregate balance sheet data published by the euro area and the U.K. for banks, other financial firms, and non-financial firms. 